\title{
SUSTAINABLE CULTURAL HERITAGE MANAGEMENT: EXAMPLE OF TROY ARCHAEOLOGICAL SITE ${ }^{1}$
}

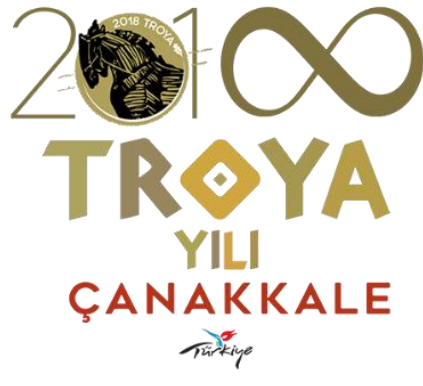

Yayın Bilgileri

Kabul tarihi: 03.12.2018

Yayın tarihi: 28.02.2019

Yazar Bilgileri

*ORCID: 0000-0001-6822-7445

*Email: erdogan@comu.edu.tr

**ORCID: 0000-0002-6174-5722

**Email: sermin.atak@comu.edu.tr
*Dr. Öğr. Üyesi Melike ERDOĞAN ** Dr. Öğr. Üyesi Şermin ATAK ÇOBANOĞLU

\begin{abstract}
Sustainable cultural heritage management is a process that local community are active with institutions in the process of determining the goals for conservation and utilization in the cultural heritage areas, planning, application and inspection of activities to be carried out. Turkey is a wealthy country from the point of cultural heritage due to historical background. 17 places in Turkey are situated in the world heritage list by UNESCO. One of these places is the ancient city of Troy which has a long historical background. The aim of the study is revealing the things to be done in order to maintain the sustainability of the ancient city of Troy with jointly management. The study was carried out with an interview with public institutions, delegates of public sector, local community and nongovernmental organizations. As the result of interviews, it was determined that sustainability of cultural heritage values of ancient city of Troy was tried to be provided with a participative management model. It is recommended that making a management plan for ensuring for the sustainable cultural heritage management of the ancient city of Troy should be made, the interinstitutional coordination should be improved, and the public participation should be increased.
\end{abstract}

Key Words: Sustainability, cultural heritage, Troy, administration, Çanakkale.

\footnotetext{
${ }^{\mathbf{1}}$ This article is extended version of the paper was presented in 7 th International Conference on Business Administration in 3- 5 May 2018.
} 


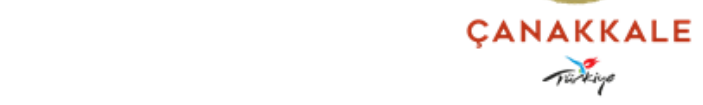

Gastroia: Journal of Gastronomy and Travel Research, Vol. 3, Issue 1, 35-58, 2019

Sustainable Cultural Heritage Management: Example of Troy Archaeological Site

Melike ERDOĞAN, Şermin ATAK ÇOBANOĞLU

\section{INTRODUCTION}

Cultural heritage represents the universal values that must be preserved for everyone today and in the future. According to the Culture Council Report of the Ministry of Culture and Tourism, Turkey, starting from prehistoric period until today, has the works of various cultures and is the one of the countries that has maximum varieties in terms of cultural heritage values. The areas recognized as world heritage must be protected areas to enable the living people in and will be living in all over the world to visit and know there. Sustainable cultural heritage areas should be managed by a management plan based on a conservation and utilization balance that will allow for the development of existing societies and the protection of their culture. Troy was added to the World Cultural Heritage List in 1998. The Troy archaeological site is one of the most well-known areas in the world and one of the areas where sustainable cultural heritage management must be successfully continued.

In the study, firstly, knowledge about the concept and development of sustainable cultural heritage management was given. The sustainable cultural heritage management of Troy archaeological site was evaluated within the framework of interviews with stakeholders in the application part.

\section{Concept of Cultural Heritage}

Cultural heritage is important in terms of ensuring the continuity of traditions and correct steps towards the future with taking advantage of experiences of previous generations throughout history. Cultural heritage is defined as any tangible and intangible assets that relevant to history of a society, identifies it and has the qualities of local and universal value that reached to day with vital continuity (ISMEP, 2014: 11-12).

Cultural heritage concept is a concept that includes almost all material objects which relevant to cultural traditions. Cultural heritage is classified as tangible cultural heritage, non-tangible cultural heritage, underwater cultural heritage and natural heritage. Tangible 


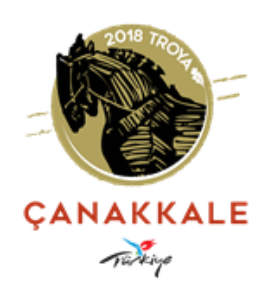

Gastroia: Journal of Gastronomy and Travel Research, Vol. 3, Issue 1, 35-58, 2019

Sustainable Cultural Heritage Management: Example of Troy Archaeological Site Melike ERDOĞAN, Şermin ATAK ÇOBANOĞLU

cultural heritage is also divided into two as movable and immovable cultural heritage. Movable cultural heritage includes books, artifacts, artistic and historical artifacts and immovable cultural heritage includes monuments, archaeological sites historical town fabrics (Daifiku, 1968: 19). Underwater cultures composed of lagans, underwater inclusions and towns, natural heritages consists of natural sites that have cultural dimension, cultural landscapes, physical, biological and geological formations.

\section{Cultural Heritage In Legal Arrangements}

As a result of damage to the cultural assets in the war and armed conflict environment the first regulations for the protection of international cultural assets have started to be made (ISMEP, 2014:15). Necessary measures for the protection of buildings and historical monuments that were not used for military purposes and dedicated to arts, science and philanthropy was ensured in Article 27 of the Hague Convention No. 4 made in 1907 concerning the wars. There are provisions directed to cultural heritage in 1931 Athens Charter and 1954 Hague Convention. It is emphasized in the 1931 Athens Charter that all elements with artistic value and historical memory must be preserved. The main factor in the creation of the 1954 Hague Convention is the destructive effects of the II. World War on the cultural heritage. It is important due to first well-attended international document in respect of conserving the cultural heritage. This contract deals with monumental architectural works, archeological sites, editions, books, movable and immovable cultural assets with artistic, archaeological and historical significance (www.unesco.org).

Convention The Protection of the World Cultural and Natural Heritage of United Nations Educational, Scientific and Cultural Organization (UNESCO) was recognized in Paris between 17 October- 21 November 1972. (Union Of Turkish Bar Associations, 2014,p. 47) Convention composed of 38 articles that includes definitions of cultural and natural heritage, the scope and qualifications of national and international conservation and regulations of responsibilities. In the convention it is stated that conservation of the unique and irreplaceable cultural assets regardless of belong to which community is important for 


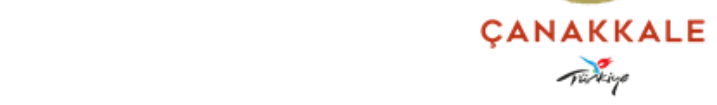

Gastroia: Journal of Gastronomy and Travel Research, Vol. 3, Issue 1, 35-58, 2019

Sustainable Cultural Heritage Management: Example of Troy Archaeological Site

Melike ERDOĞAN, Şermin ATAK ÇOBANOĞLU

all peoples of the world. It is emphasized that cultural heritage has exceptional importance thus, all humanity should consider the conservation it as part of its world heritage.

Countries that engager to convention has assignment about the determination, conservation and provide to delivery to future generations of cultural heritage. Also, it is stated that these countries have claim about getting financial, artistic, technical support and help and developing international cooperation in order to fulfill this assignment. For developing international cooperation, World Heritage Committee, International Council on Monuments and Sites (ICOMOS), World Heritage Fund, World Heritage List mechanism has been created (Union Of Turkish Bar Associations, 2014: 50-57).

Establishment or promotion national, official, private foundations and associations by Engager countries to convention in respect of convention of cultural heritage are the provisions of the contract.

Not only UNESCO, but also Council Of Europe contributed to conservation of cultural heritage with recognizing various conventions. The European Cultural Convention which was prepared by Council Of Europe in 1954, the provision of European countries to take measures to conserve the common cultural heritage and to improve the national participation of member countries are regulated (Köksal, 2017: 353). Venice Charter, important documentation with regard to cultural heritage was prepared in 1964. With the $1^{\text {st }}$ article of this charter, cultural artifacts and great works of art were included in the content of the concept of the ancient monument. It has been decided that the monuments should be conserved in such a way as to provide continuity with using scientific and technical methods (www.icomos.org.tr/).

Convention for the Protection of the Architectural Heritage of Europe was prepared by Council Of Europe in 1985. Monuments, building groups and archaeological sites are described in this convention. Convention also includes the provision that each party each party to take legal measures to conserve the heritage and undertake the conservation of 


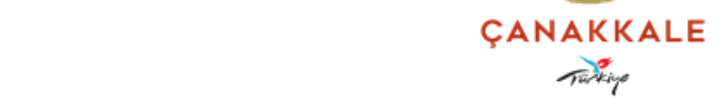

Gastroia: Journal of Gastronomy and Travel Research, Vol. 3, Issue 1, 35-58, 2019

Sustainable Cultural Heritage Management: Example of Troy Archaeological Site

Melike ERDOĞAN, Şermin ATAK ÇOBANOĞLU

these places with methods that appropriate the country or region (Turkish Bar Association, 2014: 140-141).

Convention on the Protection of the Archaeological Heritage of Europe was prepared by Europe Council in 1992. It is a convention that the Council of Europe countries have developed upon the objective of removing the problems of the archaeological heritage until that day, in order to improve cooperation with the aim and to take principle decisions. This convention aims to improve the conservation methods by emphasizing the importance of archaeological heritage in terms of human history (Turkish Bar Association, 2014: 199201).

The Framework Convention on the Value of Cultural Heritage for Society was organized by the Council of Europe in 2005. This Convention is significant to emphasize the importance of cultural heritage management to be pursued through a sustainable approach. In this convention, heritage is examined as part of an economic development model based on sustainable resource utilization principles, a resource for human development, emphasis of cultural diversity and development of intercultural dialogue (Güngör, 2018).

When we examine legislative regulations made on the internationally in the historical process, it is possible to say that the content of the concept of cultural heritage was expanded. It is also emphasized that the cultural heritage is common value of all humanity and remarked the importance of conservation.

\section{The Importance Of Conserving Of Cultural Heritage}

Cultural heritage that is the identity, symbol of continuity and proof of societies includes historical- documental, aesthetic-artistic, symbolic, social, economic, religious and nonmaterial an in fact political values (ICOMOS Türkiye, 2013: 1). Monuments and sites are conserved due to: curiosity, identity, spiritual and symbolic values, documental, historical, aesthetic, scientific and urban values etc. cultural values and social, economical, political and functional etc. usage values (Köksal, 2017: 346-347). 


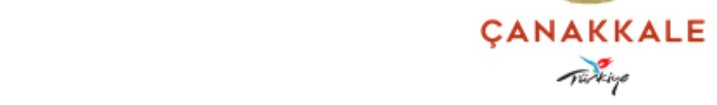

Gastroia: Journal of Gastronomy and Travel Research, Vol. 3, Issue 1, 35-58, 2019

Sustainable Cultural Heritage Management: Example of Troy Archaeological Site

Melike ERDOĞAN, Şermin ATAK ÇOBANOĞLU

The image that cultural heritage areas provide to places where they located reveals the importance of cultural heritage management. These areas are both an investment and a advantage for the cities that are trying to gain their place in the global competition by branding (Aksoy ve Ünsal, 2012: 8).

The fact that individuals have tie with people who lived in the previous period contributes the individuals acquire sense of belonging and their education (Rojas, 2013: 3). It creates a basis to culture within the cultural heritage as well as it fulfills a tie function between the past and the future. For that reason, it is important that countries establish sustainable cultural heritage management.

Primarily legal arrangements must be made in this regard to conservation of cultural heritage. Presence of provisions in legislative regulations intended for damage and robbery to cultural property are important in terms of successful conservation strategy. Having educated and conscious staff is also important to successful conservation (Daifiku, 1968: 21). Redress the balance of conservation-usage is an important need to individuals benefit from cultural heritage values. The loss of any of these properties through the damage or destruction to cultural heritage means that become poor of the heritage of all people in the world (İşlevsel IIlkeler, 2008). In this context, the conservation of cultural heritage with a sustainable approach is important for all people in the world.

\section{The Importance Of Sustainable Cultural Heritage}

Sustainability concept was used in "World Conservation Strategy" for the first time which was prepared by International Union for Conservation of Nature (IUCN) in 1980. It is emphasized that ensuring the sustainability, conservation and development idea must be considered together (Bozlağan, 2005: 1017-1018). The concept of sustainable development has started to be commonly used with the report of Our Common Future Prepared by the UN Commission on Environment and Development in 1987 (Keleş ve Hamamc1, 2005: 169). In our Common Future report, sustainability is defined as the realization of the needs of today, without jeopardizing future generations' ability to meet their own needs. 
Sustainable development provides the opportunity in the matter of realizing expectations for future needs while ensuring that basic needs are met in real time for all (Ortak Geleceğimiz Raporu, 1987: 72). Everyone statement that involved in the concept of sustainable development extends the content and brings in a global qualification. To ensure sustainable development it is aimed that a political system that will ensure the active cooperation of citizens in decision-making, creating a sustainable output growth, developing harmonious and solution oriented social relations between the social groups affected by the sectors and sectors and developing a management system that has the ability to conserve the ecological base and self-betterment when the development performs (Ortak Geleceğimiz Raporu, 1987: 96).

Conserved areas have place among the environmental indicators of sustainable development. Cultural heritage elements also need to be managed with the sustainability framework. The importance of this subject is highlighted by UNESCO in the introduction of Convention The Protection Of The World Cultural And Natural Heritage "Cultural heritage and natural heritage are threatened not only by traditional deterioration but also by increasingly dangerous decay and destruction that exacerbate this situation by changing social and economic conditions". In cultural heritage management, it is necessary to take into consideration the environment and other elements with cultural properties. In this context, a manner of rule should be developed that answers the question of how and for whom conservation will be and how sustainability can be ensured according to the changing needs of the society (Aksoy ve Ünsal, 2012: 11).

Handing the cultural heritage down to next generations depends on the works that gather different areas of expertise, such as conservation, usage, interpretation, informing and presenting. Sustainable cultural heritage management can be described as mentioned work considered in frame of a systematic and participatory manner of rule (Aksoy and Ünsal, 2012: 11). 


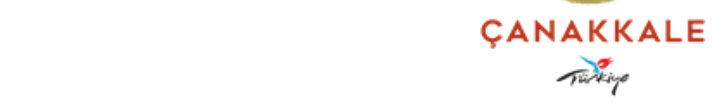

Gastroia: Journal of Gastronomy and Travel Research, Vol. 3, Issue 1, 35-58, 2019

Sustainable Cultural Heritage Management: Example of Troy Archaeological Site

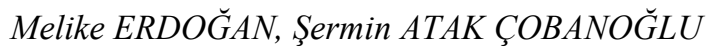

In order to apply sustainable cultural heritage management, the concept of management plan was developed. A new concept of "management planning" is aimed at sustainability of this value in a reciprocal and productive relationship with the living people with adopting the value of the heritage areas both by the local community and by the visitors. UNESCO The Intergovernmental Committee for the Protection of the World Cultural and Natural Heritage emphasizes the concept of the management plan in functional principles for the preservation of world heritage. The committee defines the management plan as "a management system that provides effective conservation of a cultural heritage area for both present and future generations". While creating conservation objectives in management plan, it is stated that to sustainability of heritage properties must be come forward with considering the development problems and legitimate needs of local communities and in compliance with this. An effective management system for cultural heritage includes planning, application, monitoring, evaluation and feedback based on participation of all stakeholders. The ecological and cultural use of cultural heritage elements must be based on sustainability.

A successful management plan is a process involving the application, which does not end with making the plan. It is relevant to the future, reveals the possible reasons and results of current decisions that determine the alternative route map of action. It is a mechanism that allows to think about threats, opportunities and other challenges. The management plan, which includes value judgments, determines how conservation should be according to changing internal and external conditions. The management plan should be adaptable to changing objectives and conditions due to it is an ongoing process (Thomas et al., 2003: 5).

Before the management plan is made, goals and objectives must be determined in accordance with continuity, participation and scientific principles. The management plan should be included nature conservation, regulation of visitor density and sustainable revenue generating activities at the local level. Also it should be includes physical, social and economic aspects. Achieving sustainability depends on ensuring the participation of all 


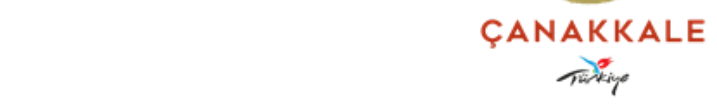

Gastroia: Journal of Gastronomy and Travel Research, Vol. 3, Issue 1, 35-58, 2019

Sustainable Cultural Heritage Management: Example of Troy Archaeological Site

Melike ERDOĞAN, Şermin ATAK ÇOBANOĞLU

stakeholders who are interested in cultural heritage areas and making decisions with consensus. Participation of all stakeholders pays dividends in making more effective and correct decisions (Güneş, 2011: 51-52; Demirayak, 2006: 162).

Countries made legislative regulations in accordance with application of management plan to ensure sustainable cultural heritage management. With amending 2863 Code Of Protection Of Cultural And Natural Properties, provisions related to the concepts of management area and management plan were added in Turkey in 2004. Management area is "protected areas, archeological sites and interaction sites that were established to ensure coordination between central and and local governments and non-governmental organizations in planning and conservation and their borders determined by Ministry with received opinions of related institutions in order to effectively conserve, sustain, evaluate, develop around a certain vision and theme within the natural unity of the interaction fields, to meet with the cultural and educational needs of the society."

"Management plan"; are plans that shows protection and development project, which takes into consideration the conservation development plan or excavation plan and landscape plan or business project's annual and five-year application stages and budget and reviewed in every five years in order to ensure the in order to ensure the conservation, sustain and evaluation of the management area. It is possible to say that these provisions emphasize the sustainability and jointly management approach in cultural heritage management. It is important to determine that local governments and nongovernmental organizations except central administration will be effective in both conservation and planning.

\section{Application}

Turkey is one of the richest countries in terms of cultural heritage and abundance of kinds and samples. Anatolian territories had been hosted to different civilizations in historical process. (Köksal, 2017: 360) There are 17 places from our country in UNESCO World Heritage List. Historic Areas of Istanbul, Great Mosque and Hospital of Divrigi (Sivas), 
Hattusa (Bogazköy)- the Hittite Capital - (Corum), Nemrut Dag (Adıyaman- Kahta), Xanthos-Letoon (Antalya - Mugla), City of Safranbolu (Karabük), Archaeological Site of Troy (Çanakkale), Edirne Selimiye Mosque and its Social Complex (Edirne), Neolithic Site of Catalhöyük (Konya), Pergamon and its Multi-Layered Cultural Landscape (İzmir), Bursa and Cumalıkızık: the Birth of the Ottoman Empire (Bursa), Diyarbakır Fortress and Hevsel Gardens, Ephesus (İzmir), Archaeological Site of Ani (Kars), Aphrodisias (Aydın), culturally and Göreme National Park and the Rock Sites of Cappadocia(Nevşehir) Hierapolis-Pamukkale (Denizli) both were taken the list as both cultural and natural heritage (www.kulturvarliklari.gov.tr).

The ancient city of troy which consists of the subject of the study was taken to the World Heritage List in 1998. The ancient city of Troy, which dates back to $3000 \mathrm{BC}$, is 9 cities built on top of each other. Troy is the place where Homer believed to live in the 8th century BC and the Trojan War which was described in the Iliad. The Trojan War, known as the first fight between the East and the West, caused the battlefield to be blessed with the epics described. For that reason, Troy is important in terms of world cultural heritage (Aslan, 2016: 20-21, 251).

The ancient city of Troy is the second most known cultural heritage of the world after Jerusalem and has a high reputation due to the influence of outputs of various disciplines of 7 continents (The Ministry of Culture and Tourism, 2018). For this reason, it is important that the ancient city of Troy is managed in terms of a socially, economically and culturally sustainable perspective. 2018 was officially recognized as the Trojan year by the Ministry of Culture and Tourism on the 20th anniversary of the Trojan Ancient City was taken to the world heritage list to ensure the sustainability of the ancient city of Troy with creating a strong perception management. Within the scope of 2018 Troy year, works are conducted based on all stakeholders participation. The application part of the work was conducted through interviews with the stakeholders who participated to the activities within the scope of the Troy year. 
Gastroia: Journal of Gastronomy and Travel Research, Vol. 3, Issue 1, 35-58, 2019

Sustainable Cultural Heritage Management: Example of Troy Archaeological Site

Melike ERDOĞAN, Şermin ATAK ÇOBANOĞLU

Table 1: Stakeholders of the sustainable cultural heritage management of troy ancient city

\begin{tabular}{|l|l|l|l|}
\hline Public Organizations & Private Sector & $\begin{array}{l}\text { Nongovernmental } \\
\text { Organizations }\end{array}$ & Local Community \\
\hline $\begin{array}{l}\text { Governorship Of } \\
\text { Çanakkale }\end{array}$ & $\begin{array}{l}\text { İÇDAŞ } \\
\text { Provincial Directorate }\end{array}$ & $\begin{array}{l}\text { TÜRSAB Group } \\
\text { Of Culture And }\end{array}$ & Chamber of Guides \\
Tourism & & $\begin{array}{l}\text { Village Officers } \\
\text { Trainees }\end{array}$ \\
Çanakkale Brand & & \\
Office Of Nature & & \\
Conservation And & & \\
National Parks & & \\
Çanakkale Regional & & & \\
Directorates Of & & \\
Cultural And Natural & & & \\
Heritage Conservation & & & \\
Board & & & \\
Çanakkale Museum & & & \\
Directorate & & & \\
Çanakkale & & \\
Municipality & & & \\
Çanakkale Onsekiz & & & \\
Mart University & & & \\
\hline
\end{tabular}

\section{Opinions Of Public Institutions On The Management Of Sustainable Cultural Heritage Of Troy Antique City}

\section{Governorship Of Çanakkale}

An interview was held on 18.04.2018 with the lieutenant governor T. Yilmaz, who was in charge of the Trojan year works. "It is the most important issue to tell and understand that Troy is the archaic value of Anatolia" said Yulmaz in interview. Anatolia should protect Troy It is necessary to protect of Troy due to the fact that the most important base of accumulation of Anatolian civilization and the first area of the East-West fight. He said that "This effort is a cultural move and is intended to raise awareness of the land to which it belongs." At the same time, he stated that in order to ensure the sustainability of the ancient city of Troy, located in the national park area, a unique destination management model could be developed under the coordination of the governor. It is emphasized that 


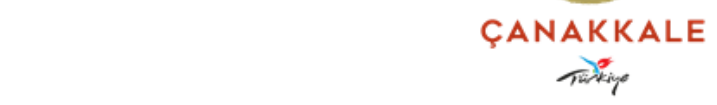

Gastroia: Journal of Gastronomy and Travel Research, Vol. 3, Issue 1, 35-58, 2019

Sustainable Cultural Heritage Management: Example of Troy Archaeological Site

Melike ERDOĞAN, Şermin ATAK ÇOBANOĞLU

this model will be aimed at coordination between institutions and will reduce resource consumption.

\section{Provincial Directorate Of Culture And Tourism}

In an interview with K. Dokuz on 30.03.2018, the Director of Culture and Tourism he said "Çanakkale is a wealthy city in terms of natural and cultural heritage. It is and Mediterranean country that have Blue Beach after Spain. 2018 is an important actor. There are two important issues in Çanakkale. The first one is martyrs' cemeteries and second one is Troya."

He remarked that there is a misinformation in the world that Troy is in Greece. He stated that they involved in introducing activities of both Turkey and Troy in 100 countries thanks to Troy year as The Ministry of Culture and Tourism. Within the scope of the promotional activities, model mannequins were charged this year, and dresses used in Troy were put on models in Berlin. In addition, a huge Trojan Horse model was used at the Berlin Fair. The books of Prof.Dr.Rustem Aslan, the head of the Trojan excavation area, were translated into English, German and Chinese languages and 10,000 copies were published.

With the collaboration of ministry and Çanakkale Onsekiz Mart University brainstorming was made with the chiefs of departments with emphasizing the importance of collaboration and sustainability two meetings were held in Dardanos and commitments were made. Also, a meeting was held with the student club presidents. They support with hanging and following announcements and banners in the university. In addition, some works such as publicity are realized by private sector by contract. However, these works are being developed in cooperation with student clubs. There is a teacher take charge in the each project with executive committee from university. The tender of Environmental Plan was made. 


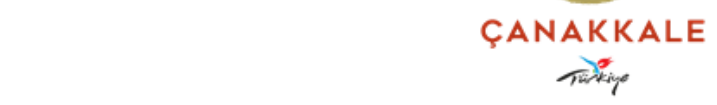

Gastroia: Journal of Gastronomy and Travel Research, Vol. 3, Issue 1, 35-58, 2019

Sustainable Cultural Heritage Management: Example of Troy Archaeological Site

Melike ERDOĞAN, Şermin ATAK ÇOBANOĞLU

He stated that he cooperated in the destination for sustainability. He stated that there is also a need for public-private cooperation at the local level. He stated that the partnership of public and private institutes is important to ensure economic sustainability. He describes it as an initiative that render the sustainable of Troy 2018 project collaboration.

\section{Çanakkale Regional Directorates Of Cultural And Natural Heritage Conservation}

\section{Board}

In an interview with E. C. Esirgemez on 04.04.2018, Deputy Regional Director of Çanakkale Cultural and Natural Heritage Preservation Board he said that "All work is being done to protect the Troy archeological site. The environmental project is being prepared as a modern sustainable project. It is aimed at increasing the ambulatory of the area with the project. Farther consolidation is envisaged in the Troy archeological site using with steel material". He stated that the committee established after natural disasters such as earthquakes in the Troy archeological site inspected and evaluated the cost of damage. This application is important to conserve the archeological site as as sustainable. He pointed out that restoration projects should be done in the archeological site. He emphasized that it is important to open the Trojan Museum in this regard that the archeological site can not be understood in this way. He indicated that archeological site could be better understood with supporting the museum with three dimensional works and visuals. Also he pointed out that the necessity of establishing management areas by making a archeological site management plan in terms of sustainable cultural heritage management.

\section{Çanakkale Brand Office Of Nature Conservation And National Parks}

In an interview with U. Elcin on 17.04.2018, Chief of Troy Historical National Park, he stated that "The activities are carried out according to the Secular Development Plan in Troy National Park. In order to ensure the sustainability of the national park's resource values based on scientific researches within the conservation and usage balance, revision studies of this plan have been going on for a year and a half with the participative method. 


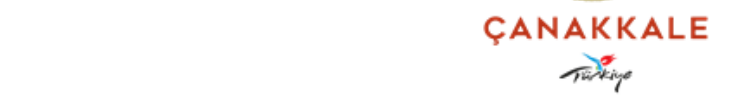

Gastroia: Journal of Gastronomy and Travel Research, Vol. 3, Issue 1, 35-58, 2019

Sustainable Cultural Heritage Management: Example of Troy Archaeological Site

Melike ERDOĞAN, Şermin ATAK ÇOBANOĞLU

Infrastructures and guidance effort to good farming are made. It is necessary to provide a balance of nature and culture in this region. Biological Diversity Inventory Study of Çanakkale is being conducted with Onsekiz Mart University Faculty of Arts and Sciences " Also he indicates the works to provide accessibility, inform flora and fauna and extensification of good farming applications are made. He emphasizes that the protection point of view changes and protection can be realized by paying attention to the carrying capacity of the environment. He pointed out to importance of introducing of national parks, informing and enabling of meeting of national park visitors needs. He made suggestions for making sculptures that reflect Troy for foreign tourists with applications such as The Hektor plant or The Trojan horse plant in the molds. He stated that they make common works with nongovernmental organizations such as travel agents, TÜRSAB and chamber of guides in the area of Troy National Park. He describes the Troy 2018 year as a sustainable activity and emphasizes that it must be repeated every year.

An interview with M. K. Cankurtaran on 02.04.2018, Engagement manager of Troy Archeological Site, stated that " 15 staff are working and more staff are required. Threedimensional description is being made with the data matrix system by means of smartphones and signboards. In addition, the recorders were renewed. With We Are Anadolu project, 1800 students are planned to come. Primary and secondary school students in Çanakkale visit the archeological site in 2018. Between 2017 and 2018, the guidance daybook was published in 4 languages. Opening a Troy Museum and bringing Truva public treasury is very important. The museum is scheduled to be completed in July." He stated that they subsidize the equipment when Tevfikiye Village needs.

An interview with G. Güzel on 16.04.2018, Media and Communication Coordinator of Troy Year Coordination Center was charged from Çanakkale Onsekiz Mart University to support Troy year works, said that "The determination of 2018 as the Troy year was made in line with the proposal from non-governmental organizations. It is a project that was emerged as a result of the idea of doing something together for Çanakkale. 2018 Troy Year 


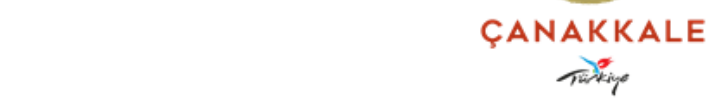

Gastroia: Journal of Gastronomy and Travel Research, Vol. 3, Issue 1, 35-58, 2019

Sustainable Cultural Heritage Management: Example of Troy Archaeological Site

Melike ERDOĞAN, Şermin ATAK ÇOBANOĞLU

project idea were offered to Orhan Tavlı, governor of Çanakkale, by Armağan Aydeğer and Ahmet Çelik who are the council members of Çanakkale Chamber Of Commerce. With the support of the Governorship of Çanakkale, the Executive Committee has been established and works has begun. This work was created a common mind and a common synergy. "

İÇDAŞ, GESTAŞ, Kale Group, Turkish Airlines, South Marmara Development Agency make important contribution to the project. Various events are held to introduce Troy at international fairs by The Ministry Of Culture And Tourism. Editions related to Troy are published in the language of the hosted country of fair. The awareness of Trojan Horse model is being tried to increase with exhibiting fairs. He stated that the biggest lack of Troy year project that is an activity that started without budget.

\section{Opinions of Private Sector Organizations on the Management of Sustainable Cultural} Heritage of Troy Antique City

The excavation works of the ancient city of Troy are carried out with IÇDAŞ support. The KALE Group and OPET support the 2018 Trojan Year project. OPET makes active works in Tevfikiye Village which the closest village to the Troy archaeological site. This part of the study is limited with the work that is carried out by the OPET. Various questions were asked about the work carried out to the Founding Member of OPET Board N. Öztürk.

She replied the question when the idea of joining the works in the village of Tevfikiye was occurred as: "Governorship of İstanbul made an offer us to join 2018 troy year project. Things we have done since 2006 within the scope of our Respect to History Project in the Gallipoli Peninsula, we know this region well and our love for Çanakkale caused to decide to join this project. We aim at local economic development by increasing the existing tourism potential of Troy and increase the quality of life of our citizens farther by reviving local product markets and creating employment. We decided to start the work at the Tevfikiye Village, which is the closest location to Troy archaeological site and Troy Museum that will be opened newly. The invitation of private sector organizations to work 


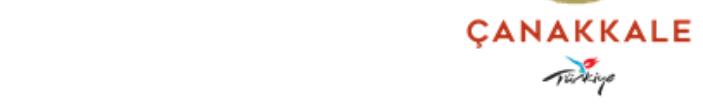

Gastroia: Journal of Gastronomy and Travel Research, Vol. 3, Issue 1, 35-58, 2019

Sustainable Cultural Heritage Management: Example of Troy Archaeological Site

Melike ERDOĞAN, Şermin ATAK ÇOBANOĞLU

jointly by public institutions is qualified to make easier sustainable cultural heritage management.

She replied the question of what the reasons was that led you to do this work as We know the region very well due to the "Respect to History Project" that we have been carrying out since 2006. Çanakkale Onsekiz Mart University has detected that our project has improved the quality of social life in the region, gained historical awareness, enriched cultural life, improved the level of economics by developing business culture. We desire to get the same results with the restoration of Tevfikiye Village. We aim to make Tevfikiye Village has the best service for domestic and foreign visitors coming to the region in 3 years. We attach great importance to Troy and Tevfikiye Project and we would like to protect our history, inform our society about Troy history and culture and maintain that period".

She stated the scope of their work and the changes that it envisages are as: "The visitors that go to the Troy archaeological site and Museum, which is our world cultural heritage, pass in front of the entrance road of this village. We want to make this village as stopover, promenade, a place that organic vegetable-fruit, souvenir shop was made and the motifs from the troy history can be seen. While restoration of Tevfikiye Village is continuing, we aim to raise the quality of social life in the region with initiating courses in different titles with the cooperation of Çanakkale Public Education Center Directorate for the people of the village. We aim to make Tevfikiye Village has the best service for domestic and foreign visitors coming to the region.

The works conducted by OPET in Tevfikiye Village are as follows:

- Landlords paint or maintain their houses in the village with specified pattern, color and motif that overlapping with 'Troy' spirit with paint support to buildings,

- Arranging the views that disturbing esthetics and decorating with flowers and afforestation around the houses,

- Renovation works according to theme of Troy period in village coffeehouse, wedding ceremony hall and community clinic, 
Gastroia: Journal of Gastronomy and Travel Research, Vol. 3, Issue 1, 35-58, 2019

Sustainable Cultural Heritage Management: Example of Troy Archaeological Site

Melike ERDOĞAN, Şermin ATAK ÇOBANOĞLU

- Renovation of the village coffeehouse and toilets in the wedding ceremony hall according to OPET standards,

- Renovation of sales stands in the village entrance. Placement of the renewed stands in the appropriate areas,

- $\quad$ Landscape study in village square,

- $\quad$ The placement of city furniture, such as benches and garbage cans, in various parts of the village,

- $\quad$ Arrangement of the entrance road of village and its surround,

- $\quad$ Placement introductory signboards of village and guide signboards to appropriate points on the roadsides,

- The building in the garden at the back of the village coffeehouse is restored in the theme of the Troy house and used as a restaurant

- Restoration of the old village mosque in accordance with the original one. This place is planned to be used as a village museum.

- Getting the unused houses in the village are major maintenance and transforming into workshops.

- In addition, the area overlooking a wide lowland, which is designed as an amphitheater called Troy Square, is transformed from Troy to historical textures, which will take time as a cruise area.

When these studies are finished, it is aimed to acquire a historical meaning with the buildings and figures that sustain the village of Troy period. These studies will make a positive contribution to ensure the sustainability of cultural heritage elements.

They stated that they received full support from the villagers in the project. The village of Tevfikiye is just opposite the Troy Museum, which is planned to open in August. It is the closest village to both the museum and the Troy archaeological site. They stated that the village people conveyed to them that they can not give due of the importance of the village properly. They stated that their supports that they provide in the beginning of the project 


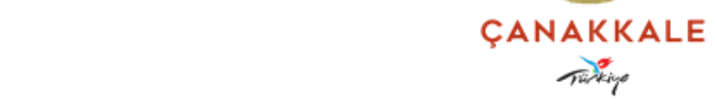

Gastroia: Journal of Gastronomy and Travel Research, Vol. 3, Issue 1, 35-58, 2019

Sustainable Cultural Heritage Management: Example of Troy Archaeological Site

Melike ERDOĞAN, Şermin ATAK ÇOBANOĞLU

are continued to beautify their village and to reflect the historical and cultural structure of Troy Historical National Park area.

First of all, village committee with 5 women, 5 men, village headman, village imam and village teacher who has knowledge and skill was established in order to follow rehabilitation studies in the village of Tevfikiye within village and provide villagers' support to the project. The village committee is organizing weekly meetings to discuss the progress of the project and to encourage village people to the project, distribute tasks and ensure the coordination of the project within the village. The support and internalization of village people's of works are important in terms of ensuring the sustainability of cultural heritage.

Opet stated that they learnt expectations of village people, works that they think about to do, course requests and subjects that they can subsidize with the Questionnaire study with the people of Tevfikiye Village within the scope of Troy Tevfikiye Village Rehabilitation Project. According to the survey, the people of Tevfikiye Village wanted that they did not receive many visitors to their villages and they wanted to change it. They stated that they want to have more information about the Trojan wars and archaeological site, and they want to reflect their villages as a Troy village. Opet stated that the almost all the people are hopeful, optimistic and excited about the Troy Tevfikiye Village Rehabilitation Project. They said that they would like to participate in the courses that will be opened with the contributions of Opet, especially those with the title of handicrafts, managership, landlord management and cookery. Consciousness cons of local community about cultural heritage elements and training will contribute to sustainability of cultural heritage with regard to social, cultural and economical.

OPET stated that they are in close touch with primarily Governorship of Çanakkale, Provincial Directorate of Culture and Tourism as 2018 Troy Year Executive Committee Special Provincial Administration Of Çanakkale, Çanakkale 18 Mart University, Regional Directorates Of Cultural And Natural Heritage Of Çanakkale, headman of Tevfikiye 
Village, District Governorship Of Eceabat, Office of the Historical Area of Gallipoli Peninsula, District Municipality of Eceabat, Tevfikiye Village Committee and Provincial Directorate Of National Education of Çanakkale within scope of Troy Project. All public institutions and organizations mentioned above stated that they are pleased working together with Tevfikiye Village rehabilitation project in the scope of 2018 International Trojan Year. The fulfillment of the works carried out within the framework of the participative management approach will provide efficiency in the making decisions and application of decisions.

\section{Opinions of Nongovernmental Organizations on the Management of Sustainable Cultural Heritage of Troy Antique City}

In the interview with A. Celik, General Secretary of TÜRSAB Çanakkale and council member Çanakkale Chamber of Commerce on 25.04.2018 he stated that they were perceived as a duty to introduce Troy, a value that the whole world knows. In order to introduce to the world that Troy is Anatolian, he declared that they offered Troy 2018 idea to the governorship and the project started with support of the governorship. He remarked that Executive Committee composed of delegates of notably Governorship of Çanakkale, public institutions and nongovernmental organizations for the project. Nongovernmental organizations emphasizes that they provides all kind of supports the projects together with merchants, chamber of guides, Çanakkale Chamber of Commerce. Conducting the project with different stakeholders is an element that facilitates sustainable cultural heritage management.

He stated that introducing Troy as Anatolian civilization of Troy year is making infrastructure and superstructure works of its surround and archaeological site and establishing a museum. They have participated in 99 international fairs to realize these aims. He emphasized that the understanding of Troy museum that will be completed at the end of August will create striking effects in terms of tourism and economy. He indicated that restaurants and way stations for tourists will be constituted in Tevfikiye village. 


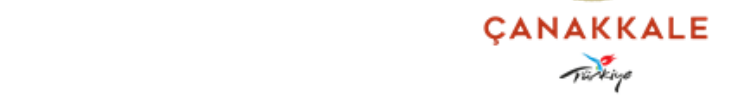

Gastroia: Journal of Gastronomy and Travel Research, Vol. 3, Issue 1, 35-58, 2019

Sustainable Cultural Heritage Management: Example of Troy Archaeological Site

Melike ERDOĞAN, Şermin ATAK ÇOBANOĞLU

\section{Opinions of Local Community on the Management of Sustainable Cultural Heritage of Troy Antique City}

In this part of the study, the results of the interviews conducted with the local managers, trainees that participated the courses which were held by OPET and course teacher in Tevfikiye village will be evaluated.

In the interview on 16.08.2018 with Mr. İsmail who is the member of Tevfikiye Village management, he stated that Troy archeological site does not contribute to village. He stated that the population of the village decreased for years due to economic reasons. He remarked that constitution of inbound route in the village for achieving economic benefit of local community from ancient city of Troy. He indicated that there is lack of infrastructure and superstructure in the village and for that reason OPET's works will be useful. It was especially emphasized that the course trainings given would contribute to economic sustainability. Çanakkale Governorship stated that received the opinions of Çanakkale Special Provincial Administration and OPET about the studies.

Courses that oriented to Tevfikiye village people were started with collaboration of OPET and Çanakkale Directorate Public Education Center that aimed at contribute to the development and renewal of the Troy region. In scope of course programme, it is planing that 344 hours education in 7 different titles between 19 February and 24 May 2018 for village people to welcome, entertain and communicate with Turkish and foreign tourists.An interview was held with the Course Teacher M. Kırıs on 16.04.2018. 15 women aged between 26-60 are attending the Kazaziye course on Mondays and Tuesdays. A Helen-like tragacanth baby-making course is held on Wednesdays and Thursdays with the participation of 14 female trainees. In addition, evening courses are held with participation of 80 female and male participants. These courses are about selfimprovement, entrepreneurship, hygiene, occupational ethics, landlord management and rural tourism. When the courses are completed, the certificate is given by the Public Education Center. The course expenses are covered by OPET and the products will be 


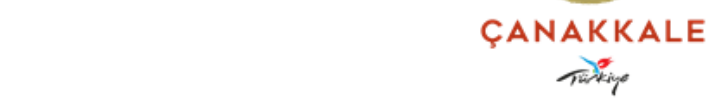

Gastroia: Journal of Gastronomy and Travel Research, Vol. 3, Issue 1, 35-58, 2019

Sustainable Cultural Heritage Management: Example of Troy Archaeological Site

Melike ERDOĞAN, Şermin ATAK ÇOBANOĞLU

exhibited in the village. The courses make a positive contribution to the human capital of the villagers and will affect the management of cultural heritage both economically and socially.

The trainees continuing on to the Kazaziye course states that in the interviews they are happy with the course. They want different courses such as diction, English, herd education to be opened. Also a trainee expressed the desire to organize a course for the making up of objects such as Trojan horse. Trainee stated that such product will be generating economical revenue due to tourists use so many candles. Most of the trainees open stands on itinerary on Troy archaeological site. Firstly they stated that their stands on the ramp part of the road and they can not make enough sale due to parking problems of cars. They stated that they want to get a space which is assigned to them to make easy selling and they want to get their stands extended.

\section{CONCLUSION AND EVALUATION}

The function of handling values of the history to future generations is the most important function of cultural heritage. Establishment of sustainable cultural heritage management is important to ensure that the specified functions can be effectively fulfilled. It is the process that the determining, planning and applying of objectives is realized through participatory management understanding in the conservation and utilization process in the field of sustainable cultural heritage management cultural heritage.

To the realization of sustainable cultural heritage management it is necessary that; developing a sense of planning that will allow future generations to recognize the area; conserving the nature and cultural heritage by providing economic development of local people, realizing a multi-partner and multi-sectoral development, increasing local participation, sustaining the applications with realization a good governance model. In the study, the sustainable cultural heritage management of Troy Archaeological Site was considered in a multi-partnered management approach. As a result of the interviews, it was determined that public institutions, private sector and nongovernmental 


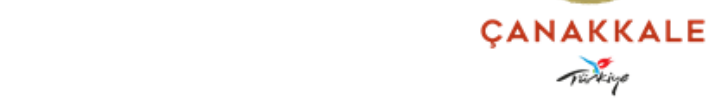

Gastroia: Journal of Gastronomy and Travel Research, Vol. 3, Issue 1, 35-58, 2019

Sustainable Cultural Heritage Management: Example of Troy Archaeological Site

Melike ERDOĞAN, Şermin ATAK ÇOBANOĞLU

organizations has working culture based on jointly management. Sustainable management that considers the conservation- usage balance that provides contribute in terms of sociocultural and economical should be exhibited. However, it is necessary to apply the management plan in order to ensure the development and continuity of this. The success of the management plan depends on the active participation of the public in the process of making and application the plan. The public participation makes easier the applications with providing to making more effective decisions.

The Troy Museum was opened as a major investment in October 2018. The Troy Museum has more than 2000 historical artifacts that are supported with text, visual dashboards, dioramas and animations. We can say that the Troy Museum makes more undertstandable the history of Troy.

\section{REFERENCES}

Aksoy, A. \& Ünsal, D. (2012). Kültürel miras yönetimi. Eskisehir: Açıkögretim fakültesi yayınları.

Aslan, R. (2016). Homeros, İlyada ve Troya. İstanbul: E Yayınları.

Bozlagan, R. (2005). Sürdürülebilir gelişme düşüncesinin tarihsel arka planı. Sosyal Siyaset Konferansları Dergisi, 40, 1012-1028.

Daifuku, H. (1968). The significance of cultural property, The conservation of cultural property. Unesco. Paris.

Demirayak, F. (2006). Türkiye'de korunan alanlar için yeni bir yaklaşım (unpublished doctorate thesis). Ankara Üniversitesi Sosyal Bilimler Enstitüsü, Ankara.

Günes, G. (2011). Korunan alanların yönetiminde yeni bir yaklaşım: katılımcı yönetim planlar1. Ekonomi Bilimleri Dergisi, 3 (1), 47-57. 
Gastroia: Journal of Gastronomy and Travel Research, Vol. 3, Issue 1, 35-58, 2019

Sustainable Cultural Heritage Management: Example of Troy Archaeological Site

Melike ERDOĞAN, Şermin ATAK ÇOBANOĞLU

Güngör, H.F. (2018, May 3). Toplum için kültürel mirasın değeri konvansiyonu. Retrieved from http://www.europanostra.org.tr.

ICOMOS Türkiye mimari mirası koruma bildirgesi (2018, May 3). Retrieved from http://www.icomos.org.tr.

İSMEP (2014), Kültürel mirasın korunması. İstanbul.

Keles, R. \& Hamamcı, C. (2005). Çevre politikası. Ankara: İmge Yayınevi.

Kültür ve Turizm Bakanlığı (2018). Kültür ve Turizm Yılı Kitapçı̆̆l.

Köksal, G. (2017). Kentsel koruma: kim için, neden, nasıl..?. In Uğurlu et al. (Ed.), Türkiye perspektifinden kent sosyolojisi çalışmaları. İstanbul: Örgün Yayınevi.

Ortak Geleceğimiz Raporu (1987). Ankara: Türkiye Çevre Sorunları Vakfı Yayını.

Rojas, E. (2013). Sustainable preservation and development of the urban heritage. Culture: key to sustainable development The Hangzhou international congress Hangzhou. China, 14-17 May 2013.

Thomas, et al., (2003). Guidelines for management planning of protected areas. Glan: The World Conservation Union.

Türkiye Barolar Birliği, (2014). Uluslararası çevre koruma sözleşmeleri. 2.nd edition. Ankara.

UNESCO (2018, May 1 ). Dünya mirası konvansiyonunun uygulanmasına yönelik işlevsel ilkeler. Retrieved from http://www.alanbaskanligi.gov.tr/files/Uygulama\%20Rehberi.pdf

2863 sayılı kültür ve tabiat varlıklarını koruma kanunu.

http://www.unesco.org/new/en/culture/themes/armed-conflict-and-heritage/conventionand-protocols/1954-hague-convention/ (accessed 10/03/2018).

http://www.icomos.org.tr/Dosyalar/ICOMOSTR_0612886001496825607.pdf 


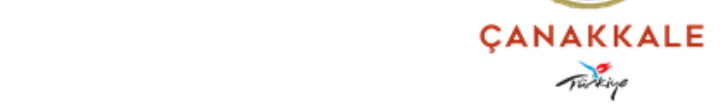

Gastroia: Journal of Gastronomy and Travel Research, Vol. 3, Issue 1, 35-58, 2019

Sustainable Cultural Heritage Management: Example of Troy Archaeological Site

Melike ERDOĞAN, Şermin ATAK ÇOBANOĞLU

(Accessed 11/03/2018).

http://www.kulturvarliklari.gov.tr/TR,44423/dunya-miras-listesi.html)

(Accessed 10/03/2018).

\section{Özgemçmiş}

\section{Dr. Öğr. Üyesi Melike Erdoğan (Sorumlu Yazar)}

Selçuk Üniversitesi İktisadi ve İdari Bilimler Fakültesi Kamu Yönetimi Bölümü mezunudur. Çanakkale Onsekiz Mart Üniversitesi Sosyal Bilimler Enstitüsü Kamu Yönetimi Anabilim Dalı'nda yüksek lisans, Dokuz Eylül Üniversitesi Sosyal Bilimler Enstitüsü Kamu Yönetimi Anabilim Dalı'nda doktora eğitimini tamamlamıştır. Halen Çanakkale Onsekiz Mart Üniversitesi Siyasal Bilgiler Fakültesi'nde öğretim üyesi olarak görev yapmaktadır.

\section{Dr. Öğr. Üyesi Şermin Atak Çobanoğlu}

Dokuz Eylül Üniversitesi İktisadi ve İdari Bilimler Fakültesi Kamu Yönetimi Bölümü Mezunudur. Dokuz Eylül Üniversitesi Sosyal Bilimler Enstitüsü Kamu Yönetimi Anabilim Dalı'nda yüksek lisans ve doktora eğitimini tamamlamıştır. Dokuz Eylül Üniversitesinde Araştırma Görevlisi ve Öğretim Üyesi olarak görev yapmıştır. 2012 yılında Çanakkale Onsekiz Mart Üniversitesi'ne geçmiştir. Halen Çanakkale Onsekiz Mart Üniversitesi Siyasal Bilgiler Fakültesi'nde öğretim üyesi olarak görev yapmaktadır. 